\title{
Influence of INF-gamma gene polymorphism in HTLV-1 proviral load
}

\author{
Rodrigo Haddad ${ }^{1,2 *}$, Maurício C Rocha-Junior ${ }^{1,3}$, Daiani C Cilião-Alves², Virgínia M D Wagatsuma1, \\ Oswaldo M Takayanagui ${ }^{2}$, Eduardo A Donadi ${ }^{2}$, Dimas T Covas ${ }^{1,2}$, Simone Kashima ${ }^{1,3}$ \\ From 15th International Conference on Human Retroviruses: HTLV and Related Viruses \\ Leuven and Gembloux, Belgium. 5-8 June 2011
}

\section{Background}

Interferon-gamma (INF- $\gamma$ ) is a key cytokine involved in the defense against intracellular pathogens, such as HTLV-1, by coordinating the expression of immunologically relevant genes. Previous studies showed the importance of this cytokine on HTLV-1-related pathogenesis. Thus, we have investigated the possible association between IFN- $\gamma$ gene single-nucleotide polymorphism linked to high and low producer phenotypes (IFN- $\gamma$ $[+874 \mathrm{~T}$ (high) $\rightarrow \mathrm{A}($ low) $])$ and risk of development of symptoms related with HTLV-1 infection and proviral load.

\section{Methods}

The polymorphism +874 T/A of INF- $\gamma$ was analyzed by PCR-SSP in 93 patients HLTV-1 positive (HAC + HAM), stratified according to the presence (HAM, $\mathrm{n}=50)$ or not (HAC, $\mathrm{n}=43)$ of symptoms, and healthy controls $(n=150)$. Proviral load of infected patients (HAC and HAM) was determined by realtime PCR.

\section{Results}

No significant difference was observed for allelic and genotypic frequencies of the $+874 \mathrm{~T} / \mathrm{A}$ polymorphism of INF- $\gamma$ when correlated with HAC, HAM and healthy controls groups. The median of proviral load was lower in HAC than HAM group $(\mathrm{p}=0.0131)$. Also, the $\mathrm{p}$-value is very close to significance $(\mathrm{p}=0.0523)$ for $+874 \mathrm{TT}$ genotype (high producer of INF- $\gamma$ ) and low proviral load, compared to the genotypes $+874 \mathrm{AA}$ and +874AT.

* Correspondence: rodrigohaddad@hemocentro.fmrp.usp.br

${ }^{1}$ Regional Blood Center of Ribeirão Preto, Ribeirão Preto, Brazil

Full list of author information is available at the end of the article

\section{Conclusion}

Despite the lack of significant associations, the low proviral load appears correlated with high producer of INF$\gamma(+874 \mathrm{TT})$ genotype. Increasing the number of patients may lead to statistical relationship of the $+874 \mathrm{TT}$ genotype with low proviral load.

\section{Acknowledgements}

Financial Support FAPESP, CNPq, CTC/FUNDHERP and INCTC.

\section{Author details}

${ }^{1}$ Regional Blood Center of Ribeirão Preto, Ribeirão Preto, Brazil. ${ }^{2}$ Faculty of Medicine of Ribeirão Preto, University of São Paulo, Ribeirão Preto, Brazil. ${ }^{3}$ Faculty of Pharmaceutical Sciences of Ribeirão Preto, University of São Paulo, Ribeirão Preto, Brazil.

Published: 6 June 2011

\section{doi:10.1186/1742-4690-8-S1-A119}

Cite this article as: Haddad et al:: Influence of INF-gamma gene polymorphism in HTLV-1 proviral load. Retrovirology 2011 8(Suppl 1): A119.
Submit your next manuscript to BioMed Central and take full advantage of:

- Convenient online submission

- Thorough peer review

- No space constraints or color figure charges

- Immediate publication on acceptance

- Inclusion in PubMed, CAS, Scopus and Google Scholar

- Research which is freely available for redistribution
() Biomed Central 